\title{
REVISED Case Report: Gollop-Wolfgang Complex in a 5 month old
}

\section{baby [version 3; peer review: 2 approved, 1 approved with}

\section{reservations]}

\author{
Ihtesham A. Qureshi, Rohit Kumar Gudepu, Ravikanth Chava, Sravya Emmani, \\ Syed Husain Asghar, Mohtashim A. Qureshi, Nimmathota Arlappa
}

Division of Community Studies, National Institute of Nutrition, Indian Council of Medical Research, Hyderabad, 500 007, India

V3 First published: 23 Dec 2014, 3:315

https://doi.org/10.12688/f1000research.5889.1

Second version: 09 Feb 2015, 3:315

https://doi.org/10.12688/f1000research.5889.2

Latest published: 24 Feb 2015, 3:315

https://doi.org/10.12688/f1000research.5889.3

\section{Abstract}

Skeletal dysplasias are disorders associated with a generalized abnormality in the skeleton. The Gollop-Wolfgang complex (GWC) is a limb deficiency disorder and an unusual limb malformation with highly variable manifestations. Here we report an interesting case of a 5-month old male baby from India with Gollop-Wolfgang Complex showing bifurcation of the right femur, ectrodactyly of both feet, ectrodactyly of left hand, syndactyly of right hand and unusual presentation of bilateral fibular agenesis and caudal (Sacrococcygeal) agenesis. The etiology of GWC in this 5 month old male baby could possibly be attributed to spontaneous gene mutation. The clinical, radiographic findings and the unusual presentation are presented in detail.

Keywords

Skeletal dysplasias, Gollop-Wolfgang complex, limb deficiency

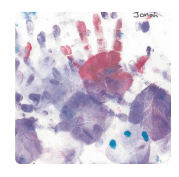

This article is included in the Rare diseases collection.

\section{Open Peer Review \\ Approval Status ? \\ 123 \\ version 3 \\ (revision) \\ 24 Feb 2015 \\ version 2 \\ (revision) \\ 09 Feb 2015

version 1 ? \\ 23 Dec $2014 \quad$ view \\ 1. Stephen Robertson, Dunedin School of Medicine, University of Otago, Dunedin, New Zealand \\ 2. Nicole Philip, Assistance Publique - Hopitaux de Marseille, Marseille, France \\ 3. Murat Bastepe, Massachusetts General Hospital, Boston, USA \\ Qing He, Massachusetts General Hospital, Boston, USA}

Any reports and responses or comments on the article can be found at the end of the article. 
Corresponding author: Nimmathota Arlappa (arlappan@yahoo.com)

Competing interests: No competing interests were disclosed.

Grant information: The author(s) declared that no grants were involved in supporting this work.

Copyright: $\odot 2015$ Qureshi IA et al. This is an open access article distributed under the terms of the Creative Commons Attribution License, which permits unrestricted use, distribution, and reproduction in any medium, provided the original work is properly cited. Data associated with the article are available under the terms of the Creative Commons Zero "No rights reserved" data waiver (CC0 1.0 Public domain dedication).

How to cite this article: Qureshi IA, Gudepu RK, Chava R et al. Case Report: Gollop-Wolfgang Complex in a 5 month old baby [version 3; peer review: $\mathbf{2}$ approved, 1 approved with reservations] F1000Research 2015, 3:315

https://doi.org/10.12688/f1000research.5889.3

First published: 23 Dec 2014, 3:315 https://doi.org/10.12688/f1000research.5889.1 


\section{REVISED Amendments from Version 2}

Based on the comments by Dr. Nicole Philip I have made changes to my previous version.

See referee reports

\section{Introduction}

Generalized disorders of cartilage and bone have been referred to as skeletal dysplasias and are associated with a generalized abnormality in the skeleton ${ }^{1}$. Gollop-Wolfgang Complex (GWC) is a rare congenital limb anomaly characterized by tibial aplasia, ipsilateral bifurcation of the thighbone and ectrodactyly ${ }^{2}$. Ectrodactyly involves the deficiency or absence of one or more central digits of the hand or foot and is also known as split hand/split foot malformation (SHFM) ${ }^{3}$. Very often, the anomalies of limbs, heart, digestive and urinary tracts and the lumbosacral vertebrae are also affected $^{4}$.

In 1980, Gollop et al. described the case two brothers with ectrodactyly and unilateral bifurcation of the femur, absence of both tibiae and monodactyly of the feet ${ }^{5}$. In 1984, Wolfgang reported a case of right femoral bifurcation and absence of tibia and bilateral central defects of the hand $d^{5}$. Lurie and Ilyina (1986) proposed the eponym GWC for the combination of femoral bifurcation with hand ectrodactyly ${ }^{6}$. Endo et al. found a total of 12 reported cases and added the case of a Japanese girl with a unique form of this malformation complex. Both hands and feet were involved and the involvement was bilateral ${ }^{2}$. The etiology of GWC is most likely an error in the complex genetic control of limb development but the exact cause is still unclear7. GWC is listed as a "rare disease" by the United States Office of Rare Diseases [ORD] of the National Institute of Health $[\mathrm{NIH}]$ and the approximate incidence is 1 in $1000,000^{8}$.

\section{Case presentation}

A 5-month old male Indian child with normal karyotype (46 XY) born to a 26-year-old primigravida, full term by C-section, presented with limb deformities associated with bilateral ectrodactyly of feet (Figure 1 and Figure 2), syndactyly of right hand (Figure 3) and ectrodactyly of left hand (Figure 4). At the medial distal third of the right femur, a large protrusion was present (Figure 1 and Figure 5). Radiographic images showed bifid femur with fibular agenesis (Figure 6), absence of right 3, 4, 5 metatarsals and phalanges, absence of left 4,5 metatarsals and phalanges of foot (Figure 7), left lateral X-ray showing caudal (sacrococcygeal) agenesis (Figure 8). Initial diagnosis was made when the parents brought the child to the out-patient department concerned about limb abnormality at the age of 3 months and the final diagnosis was made following admission to the in-patient unit at 5 months, based on both clinical presentation and radiological images. There was no detailed prenatal history available.

The parents had documented second degree consanguinity but both did not have any significant family history. Similarly, there was no history of exposure to radiation, prenatal teratogenic medications and infections during pregnancy. The mother did not smoke or

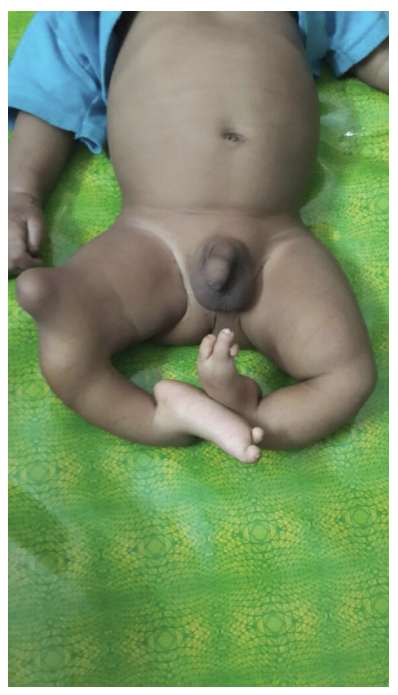

Figure 1. Limb deformities.

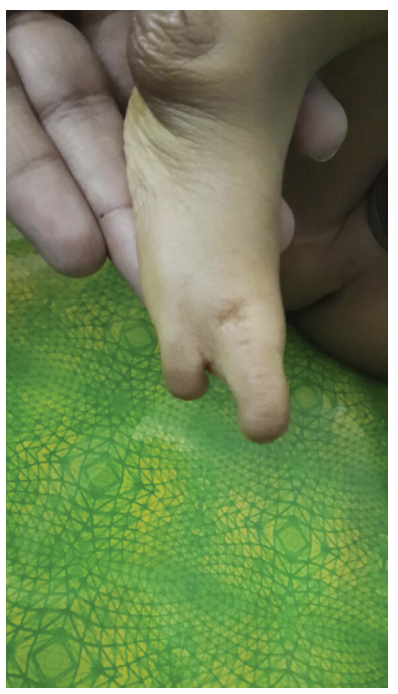

Figure 2. Ectrodactyly of toes.

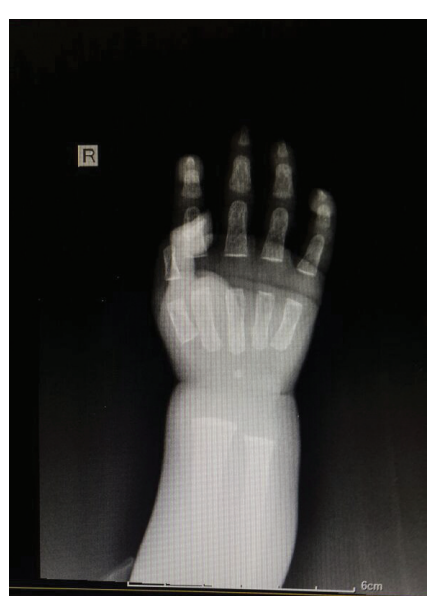

Figure 3. X-ray right hand showing syndactyly. 


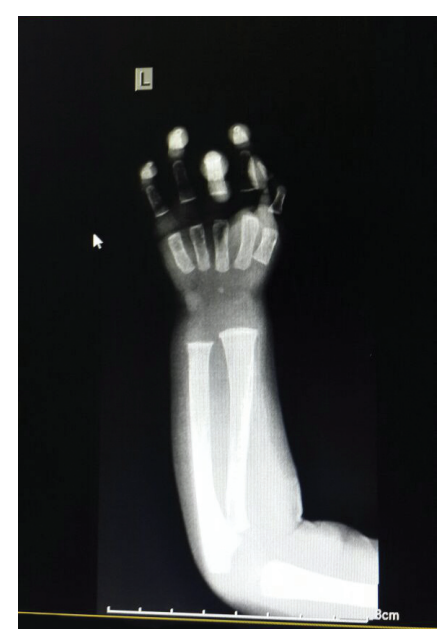

Figure 4. X-ray of left hand showing ectrodactyly

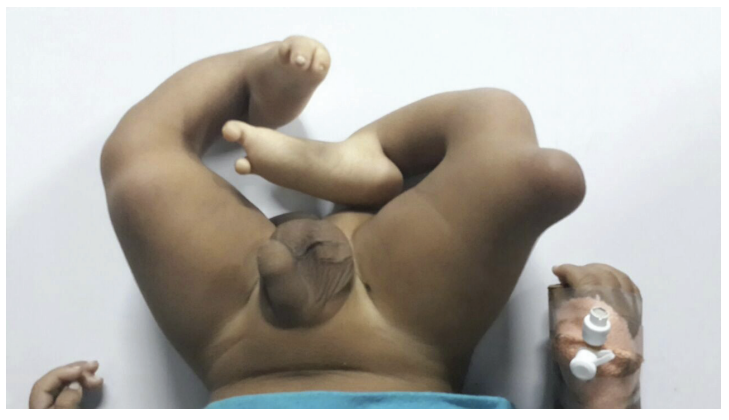

Figure 5. Protrusion over right thigh.

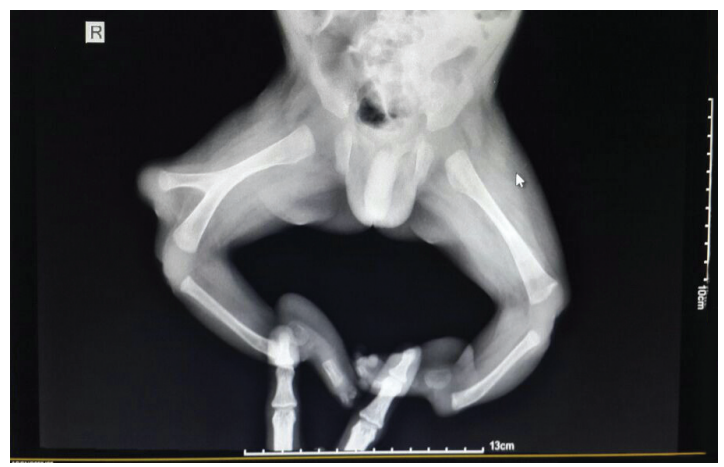

Figure 6. X-ray showing bifid femur with fibular agenesis.

drink during pregnancy. The child was breast-fed with good appetite and cry, without any bowel bladder problems, change in skin color or any cleft lip/palate. Echocardiography at the time of admittance revealed no congenital heart defects. The ultrasonography of abdomen and pelvis revealed no visceral or renal abnormalities. Surgical reconstruction treatment was advised but the parents did not give consent for treatment.

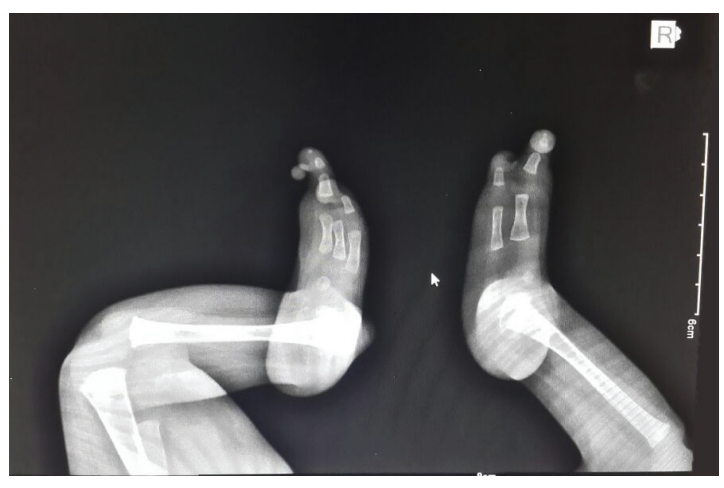

Figure 7. X-ray showing absence of right 3,4,5 metatarsals and phalanges, absence of left 4,5 metatarsals and phalanges.

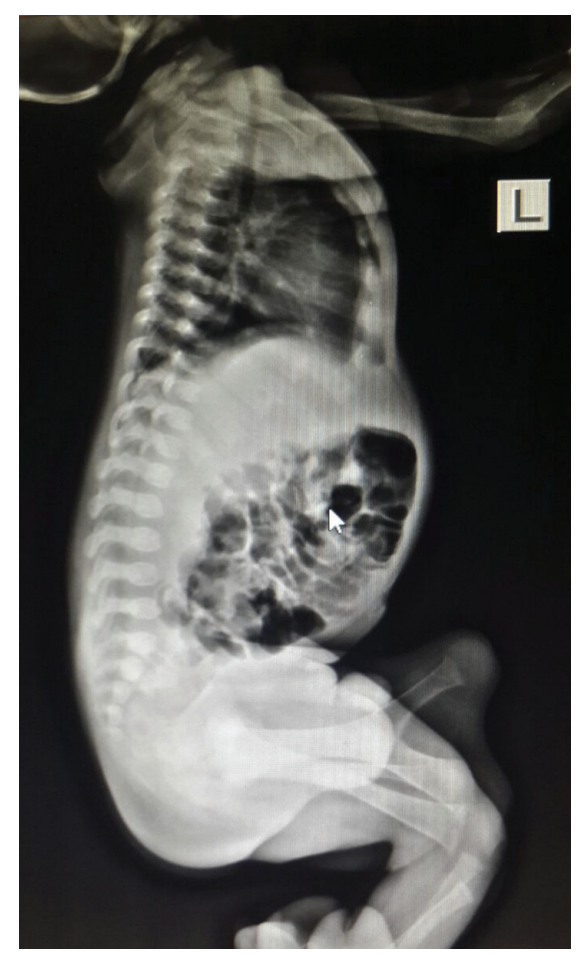

Figure 8. X-ray showing caudal (sacrococcygeal) agenesis.

\section{Discussion}

One case was reported of an Arab Muslim couple who came from a region where other consanguineous families with similarly affected individuals had been reported Kohn et al. in $1989^{\circ}$, and the autosomal recessive inheritance seemed evident in the case of a child described by Raas-Rothschild et al. in $1999^{10}$. In this case, we report a typical presentation of GWC with bilateral fibular agenesis and sacrococcygeal agenesis along with pathognomonic features of GWC (bifurcation of femur, syndactyly and ectrodactyly). There were no associated abnormalities like cleft lip/palate, tibial agenesis, 
visceral or cardiac anomalies seen in this patient. There is one documented case reported with distal femoral duplication with fibular agenesis ${ }^{11}$. The best treatment option for this patient with GWC is early knee disarticulation and resection of the protruded bifurcated femur, followed by fitting of a modern prosthesis ${ }^{12}$. This treatment was discussed with the parents of the patient at three months of age and a follow-up visit was scheduled after two months.

History of consanguinity is strongly associated with the developments of congenital anomalies among the newborn babies; there should be pre-marital genetic counselling to evaluate any impending congenital abnormalities. Similarly, antenatal check-ups are appropriate for early detection of congenital anomalies through proper screening.

\section{Consent}

Informed written consent for publication of images and clinical details was obtained from the patient's parents.

\section{Author contributions}

NA, IQ, MQ, RG have performed literature review and manuscript writing. RC helped to make the diagnosis. SA, SE helped in revision of the manuscript. All the authors approved the final version of the manuscript.

\section{Competing interests}

No competing interests were disclosed.

\section{Grant information}

The author(s) declared that no grants were involved in supporting this work.

\section{Acknowledgements}

The authors like to acknowledge the contribution of Dr. M. Bharti, Professor at the Department of Radio-diagnosis, Navodaya Medical College, India.
1. Krakow D, Rimoin DL: The skeletal dysplasias. Genet Med. 2010; 12(6): 327-341. PubMed Abstract | Publisher Full Text

2. Bos CF, Taminiau AH: A 5-year follow-up study after knee disarticulation in two cases of Gollop-Wolfgang complex. J Pediatr Orthop B. 2007; 16(6): 409-413. PubMed Abstract | Publisher Full Text

3. Moerman P, Fryns JP: Ectodermal dysplasia, Rapp-Hodgkin type in a mother and severe ectrodactyly-ectodermal dysplasia-clefting syndrome (EEC) in her child. Am J Med Genet. 1996; 63(3): 479-81. PubMed Abstract | Publisher Full Text

4. Erickson RP: Agenesis of tibia with bifid femur, congenital heart disease, and cleft lip with cleft palate or tracheoesophageal fistula: possible variants of Gollop-Wolfgang complex. Am J Med Genet A. 2005; 134(3): 315-317. PubMled Abstract | Publisher Full Text

5. Wolfgang GL: Complex congenital anomalies of the lower extremities: femoral bifurcation, tibial hemimelia and diastasis of the ankle. Case report and review of the literature. J Bone Joint Surg. 1984; 66(3): 453-458. PubMed Abstract

6. Lurie IW, llyina HG: Gollop-Wolfgang Complex in a 3-month-old girl. Am J Med Genetic. 1986; 25: 191-194. PubMed Abstract | Publisher Full Text
7. Endo $A$, Watanabe $\mathrm{K}$, Shimada $\mathrm{M}$, et al.: Bilateral involvement of hands and legs in the Gollop-Wolfgang complex. Am J Med Genet. 1998; 80(5): 529-530. PubMed Abstract | Publisher Full Text

8. http://rarediseases.info.nih.gov/gard/browse-by-first-letter/G.

9. Kohn G, el Shawwa R, Grunebaum M: Aplasia of the tibia with bifurcation of the femur and ectrodactyly: evidence for an autosomal recessive type. Am J Med Genetics. 1989; 33(2): 172-175.

PubMed Abstract | Publisher Full Text

10. Raas-Rothschild A, Nir A, Ergaz Z, et al:: Agenesis of tibia with ectrodactyly/ Gollop-Wolfgang complex associated with congenital heart malformations and additional skeletal abnormalities. Am J Med Genet. 1999; 84(4): 361-364. PubMed Abstract | Publisher Full Text

11. Cakir M, Hoefsloot LH, Orhan F, et al.: Distal femoral duplication and fibular agenesis associated with congenital cardiac defect. Indian J Pediatr. 2010; 77(2): 210-211.

PubMed Abstract | Publisher Full Text

12. Wada A, Nakamura T, Fujii T, et al.: Limb salvage treatment for GollopWolfgang complex (femoral bifurcation, complete tibial hemimelia, and hand ectrodactyly). J Pediatr Orthop B. 2013; 22(5): 457-463. PubMed Abstract | Publisher Full Text 


\section{Open Peer Review}

\section{Current Peer Review Status:}

\section{Version 3}

Reviewer Report 19 May 2015

https://doi.org/10.5256/f1000research.6622.r8336

(C) 2015 Bastepe $\mathbf{M}$ et al. This is an open access peer review report distributed under the terms of the Creative Commons Attribution License, which permits unrestricted use, distribution, and reproduction in any medium, provided the original work is properly cited.

\section{Murat Bastepe \\ Endocrine Unit, Massachusetts General Hospital, Boston, MA, 02114, USA \\ Qing He \\ Endocrine Unit, Massachusetts General Hospital, Boston, MA, USA \\ This report describes a 5-month-old patient with rare Gollop-Wolfgang Complex (GWC) disorder. The patient exhibits typical phenotypes of GWC disease, such as ectrodactylyl of the hand and bifurcation of the femur. \\ The etiology of GWC remains unknown. However, the patient's parents are second degree relatives, and other reports have described GWC patients in consanguineous families, suggesting that this disease is inherited in an autosomal recessive manner. \\ The manuscript is well-written, and I suggest it is indexed in current form. \\ Competing Interests: No competing interests were disclosed. \\ We confirm that we have read this submission and believe that we have an appropriate level of expertise to confirm that it is of an acceptable scientific standard.}

Reviewer Report 30 March 2015

https://doi.org/10.5256/f1000research.6622.r8149

(C) 2015 Philip N. This is an open access peer review report distributed under the terms of the Creative Commons Attribution License, which permits unrestricted use, distribution, and reproduction in any medium, provided the original work is properly cited.

\section{Nicole Philip}

Département de Génétique Médicale et de Biologie Cellulaire, Assistance Publique - Hopitaux de 
Marseille, Marseille, France

Competing Interests: No competing interests were disclosed.

I confirm that I have read this submission and believe that I have an appropriate level of expertise to confirm that it is of an acceptable scientific standard.

\section{Version 2}

Reviewer Report 13 February 2015

https://doi.org/10.5256/f1000research.6552.r7661

(c) 2015 Philip N. This is an open access peer review report distributed under the terms of the Creative Commons Attribution License, which permits unrestricted use, distribution, and reproduction in any medium, provided the original work is properly cited.

\section{Nicole Philip}

Département de Génétique Médicale et de Biologie Cellulaire, Assistance Publique - Hopitaux de Marseille, Marseille, France

I fully agree with the first reviewers's comments.

This paper deserves indexing as it is a very rare disorder. However, the following sentence (in the discussion) should be deleted:

"This type of skeletal dysplasia with limb deficiencies could be the result of spontaneous gene mutations and chronic exposure to a toxic substance or infectious agents that results in the disruption of normal skeletal development."

The main conclusion of this report should be that the occurrence of Gollop-Wolfgang in a consanguineous family brings further arguments to support autosomal recessive inheritance.

Competing Interests: No competing interests were disclosed.

I confirm that I have read this submission and believe that I have an appropriate level of expertise to confirm that it is of an acceptable scientific standard.

\section{Version 1}

Reviewer Report 27 January 2015

https://doi.org/10.5256/f1000research.6291.r7449 
(C) 2015 Robertson S. This is an open access peer review report distributed under the terms of the Creative Commons Attribution License, which permits unrestricted use, distribution, and reproduction in any medium, provided the original work is properly cited.

\section{Stephen Robertson}

Department of Genetics, Dunedin School of Medicine, University of Otago, Dunedin, New Zealand

This report describes a child with a typical presentation of Wolfgang-Gollop complex. The eitiology of this condition is still in doubt although some familial recurrences suggest a genetic cause. The statement in the abstract that a spontaneous mutation is possible owing to parental consanguinity does not make sense and should be deleted. In this discussion there is also a suggestion that consanguineous unions should somehow be discouraged. This is inappropriate and a breach of reproductive autonomy. Such a statement should be removed. Consanguinity is not the strong risk factor for congenital anomalies as the authors imply, conferring approximately a 2 fold enhanced risk of such problems. This assertion needs to be rebalanced.

Competing Interests: No competing interests were disclosed.

I confirm that I have read this submission and believe that I have an appropriate level of expertise to confirm that it is of an acceptable scientific standard, however I have significant reservations, as outlined above.

\section{Author Response 02 Feb 2015}

aatif qureshi,

Really appreciate your comments Dr. Stephen Robertson. I would like to hear back about my newer version of the paper.

Competing Interests: No competing interests were disclosed. 
The benefits of publishing with F1000Research:

- Your article is published within days, with no editorial bias

- You can publish traditional articles, null/negative results, case reports, data notes and more

- The peer review process is transparent and collaborative

- Your article is indexed in PubMed after passing peer review

- Dedicated customer support at every stage

For pre-submission enquiries, contact research@f1000.com 